\title{
Reconciling Trade and Culture: A Global Law Perspective
}

\author{
R Routledge \\ Taylor \& Francis Group
}

\author{
Mira Burri \\ World Trade Institute, University of Bern Law School, Bern, Switzerland
}

KEYWORDS cultural diversity, culture, digital media, international law, trade, UNESCO, WTO

Trade and culture have been perceived as antagonistic rather than as mutually supportive. Indeed, the pair is often framed as "trade versus culture," and this opposition could be particularly well-observed at the international policy- and law-making scene. With the adoption of the Convention on the Protection and Promotion of the Diversity of Cultural Expressions in 2005, the trade and culture quandary has received a clear institutional dimension. The newly installed

25 apparatus under the auspices of the United Nations Educational, Scientific and Cultural Organization (UNESCO) is meant to offset the efforts of the World Trade Organization (WTO) to progressively liberalize trade, including such in cultural goods and services.

It is the purpose of this article to look into this intensified disconnect between issues of trade and culture and to expose its flaws and the considerable drawbacks 
that it brings with it. These drawbacks, we argue, become especially pronounced in the digital media environment, which has impacted upon both the conditions of trade with cultural products and services and upon cultural diversity in local and global contexts. In this modified setting, there could have been a number of feasible "trade and culture" solutions-i.e., regulatory designs that whilse enhancing trade liberalization are also conducive to cultural policy. Yet, the realization of any of these options becomes chimerical as the line between trade and culture matters is drawn in a clear and resolute manner.

To explicate the above hypothesis, this article is structured in four sections. The first investigates the UNESCO Convention as a culmination of the efforts to resolve cultural matters outside the WTO. The second section critiques the disconnect between the issues of trade and culture, both in terms of its underlying rationale and in terms of its inadequacy to reflect the changing environment of contemporary media. Section three looks at the law of the WTO in order to see whether indeed the devil is so black as he is painted, or whether there is room for practical solutions. Section four pulls all analytical strings together, offering conclusions and some thoughts on possible routes out of the "trade versus culture" quandary and toward reconciliation of trade and culture.

\section{THE UNESCO CONVENTION: AN APPRAISAL}

The Convention on Cultural Diversity was adopted by the 33rd UNESCO General Conference in 2005 and entered into force on March 18, 2007 after a rapid ratification process. ${ }^{1}$ It is the pinnacle of multiple-track efforts spread over many years with the objective of providing a binding instrument for the protection and promotion of cultural diversity at the international level. The Convention is thus on the one hand a crystallization of some previous, mostly exhortatory acts in the fields of culture and trade, and of cultural heritage. ${ }^{2}$ On the other hand, and more importantly in the present context, the Convention is also a clear reaction to economic globalization, whose advancement has been significantly furthered by the emergence of enforceable multilateral trade rules and whose bearer, the WTO, has been perceived as the very antipode to "culture." In this sense, the UNESCO Convention as a legally binding agreement was meant to counterbalance the WTO and fill "a lacuna in public international law regarding cultural values."3

In both of the above aspects, the UNESCO Convention is said to be a remarkable success for those state and nonstate actors, who can be collectively referred to as proponents of the "cultural exception" doctrine ${ }^{4}$ and who have argued fervently for many years that cultural products are not just commodities but "reflect who we are as a people, $[\ldots]$ shape our society, develop our understanding of one another and give us a sense of pride in who we are as a nation." ${ }^{5}$ Beyond this rhetoric, however, the odd thing about the Convention is that when one looks at it closely 
70 and construes it as a treaty basis for any future undertaking aimed at protecting and promoting cultural diversity, most of the highly optimistic labels that cultural advocates put on it do not stick.

\section{Rights, Not Obligations}

As an act of international law, the UNESCO Convention contains certain rights 75 and obligations with varying degrees of binding intensity upon which the Parties have agreed. The UNESCO Convention has, however, precious few obligations, and these are formulated as mere stimuli for the Parties to adopt measures for the protection and promotion of cultural diversity rather than as genuine duties. ${ }^{6}$

Lack of action could result at worst in a state being criticized by the Inter-

80 governmental Committee or Conference of Parties on the basis of the state's own report. ${ }^{7}$ Despite the extremely limited obligations on the Parties to take action to protect and promote cultural diversity, the Convention formulates an extensive block of rights to that end. Article 6(2) of the UNESCO Convention provides a nonexhaustive list of measures that the Parties may adopt, depicting basically all

85 known cultural policy measures that states put in place, ranging from any "regulatory measures aimed at protecting and promoting diversity of cultural expressions" to the concrete example of public service broadcasting. ${ }^{8}$ This "all inclusive" approach signals that the Convention's object has been "to endorse forms of market intervention rather than to preclude them."

90 Admittedly, nonexhaustive lists are not a rare phenomenon in intergovernmental treaty making. They allow, through some vagueness and constructive ambiguity, the bringing together of an array of (at times diverging) interests and the actual closing of the deal. Yet, what makes the UNESCO Convention peculiar in this regard is the complete lack of criteria and/or mechanisms that would make these

95 definitions workable, separating the licit from the illicit cultural policy measures. The least that the Convention could have done was to insert a sort of proportionality or necessity test for measures that truly target cultural goals. ${ }^{10}$ This flaw adds up to the extremely broad and fuzzy definition of "cultural diversity" provided by the Convention ${ }^{11}$ and gives sufficient grounds to suspect protectionism.

100 This suspicion has been shared both by prominent negotiation Parties, notably the U.S., and by a host of scholars, ${ }^{12}$ who warn against abuse. The UNESCO Convention lacks the institutional or adjudicatory mechanisms that could fill in some gaps over time and cast aside these suspicions.

\section{Missing Bits and Pieces}

Next to the almost entirely missing obligations and implementation criteria, one should note that the framework of the UNESCO Convention is not comprehensive 
enough to secure the protection and promotion of cultural diversity, leaving some critical elements outside its otherwise generously defined scope of application. Some of these missing elements are related to the centrality of state sovereignty, which is intrinsic to the UNESCO Convention. Indeed, the sovereignty of the State Parties in the cultural field is included as one of the eight guiding principles underpinning the Convention, and all rights and obligations stemming from the Convention are attributed to states. Whereas this is understandable for an intergovernmental treaty, cultural rights do not correspond to national boundaries. ${ }^{13}$ It is also disappointing that no specific cultural rights, which states must respect-such as access to education or use of language of choice-did not make it into the text, ${ }^{14}$ in particular since they were acknowledged by the earlier but nonbinding UNESCO Declaration on Cultural Diversity. Furthermore, while the Convention does mention indigenous peoples and traditional cultural expressions a few times, ${ }^{15}$ the relevant provisions remain declarative in nature and again address not the rights of the indigenous peoples themselves but those of the states whose territory is affected. ${ }^{16}$ Besides this ethnocentricity in the formulation of the rights, the UNESCO Convention establishes no specific rights for media organizations, journalists, or individuals. Their interests are to be realized only through state action, if at all. ${ }^{17}$

Another vital element omitted from the regulatory domain of the UNESCO 105 Convention, except for the brief remark in the preamble, ${ }^{18}$ is intellectual property rights (IPRs). This omission is peculiar since it could be argued that IPRs are the oldest and now the most advanced system put in place with the ultimate goal of fostering creativity. ${ }^{19}$ In fact, IPRs strongly influence the creation, distribution, access, and re-use of any cultural content, ${ }^{20}$ and in subtler ways impinge upon the 110 entire cultural environment. ${ }^{21}$

Ending our critical glimpse of the UNESCO Convention, we concur with Craufurd Smith in saying that what we have "is a document that evades controversy, which establishes general objectives and frames them in purely exhortatory terms. As a political manifesto, with little legal substance, it is hardly an advance on the 115 international declarations on cultural diversity which preceded it."22 Alternatively, and less sharply, one can plainly say that what made the adoption of the UNESCO Convention possible also emptied it of some of its valuable content. This shows on the one hand the complexity of the issues that arise whenever cultural diversity is to be addressed and on the other hand, in a political context, the starkly dif- 120 ferent sensibilities and motivation of the Parties when drafting a legally binding international instrument on cultural matters.

Still, the UNESCO Convention will certainly influence the existing international agreements indirectly in the process of their interpretation. More importantly, the UNESCO Convention is likely to influence the political context of 125 international agreements by changing the power plays in negotiations and by shaping the content of future agreements. With particular regard to the WTO, this has been one of the main stimuli (if not the only one) for a number of states to 
pursue the adoption of the UNESCO Convention, in particular as recent free trade agreements (FTAs) of the U.S. have diminished flexibilities and increased the level of commitments (especially for media services) in comparison to those under the WTO.

\section{DISCONNECTING TRADE AND CULTURE: THE UNESCO CONVENTION AS PART OF THE PROBLEM RATHER THAN} THE SOLUTION

While the Convention elevates "the status of cultural diversity as a matter of international concern, just as international agreements on the environment and health have helped to underline the importance of these considerations in other international fora such as the WTO," ${ }^{23}$ we see this only partially as an advancement toward a better functioning global governance system. Indeed, and here lies our core argument, one can view the UNESCO Convention as part of the problem rather than the solution. As mentioned at the outset, it is a sign of a growing disconnection between issues of trade and culture- a disconnection that does none of these domains any good and does not reflect the developments in contemporary media markets.

\section{Flawed Understanding of the Effects of Trade Upon Culture}

The debate on trade and culture has been defined by a deeply convoluted (if not to say flawed) understanding of the effects of trade and more broadly economic globalization upon culture. While it is indubitable that "trade generates complex and often contradictory effects," 24 it is equally certain that trade is not a "zero-sum" game, ${ }^{25}$ and there are a number of ways in which trade enhances cultural flows and exchanges. In the "trade and culture" discourse, however, the common (and particularly loud) statements are that cultural diversity is becoming impoverished and almost extinguished as the globalized flow of easy entertainment coming from Hollywood dominates and homogenizes. ${ }^{26}$ This (mis)conception ${ }^{27}$ is difficult to put right or to soften at least. The discussion on "trade values" and "non-trade values" is extremely over politicized and often resembles a clash between two religions that find no channel of communication between them.

In the specific sense of cultural policy making, the debate is additionally burdened with notions of cultural and national identity that lead to national sovereignty susceptibilities. In the subcontext of policy making in audiovisual media, the discussion is further complicated since "one's view on the role of media in society is intimately bound up with one's view of democracy and the proper bounds of governmental power." ${ }^{28}$ Ultimately, all these interrelated discourses are in a profound 
sector moves from being a separable and quarantined domain of governance to its enactment as part of a whole-of-government modelling in which it emerges as a service industry in a "digital economy,", 29 and exogenously (outside the nation state), as liberalization, migration, and other forces of globalization ${ }^{30}$ induce sweeping societal shifts that make modern society increasingly homogeneous across cultures and heterogeneous within them.

Under these circumstances, it is becoming outdated and increasingly inappropriate to apply notions of cultural diversity, which "tend to favour 'billiard ball' representations of cultures as neatly bounded wholes whose contents are given and static. These understandings downplay 'the ways in which meanings and symbols of culture are produced through complex processes of translations, negotiation and enunciation,' as well as by contestation and conflict." 31 To be sure, these are precisely the perceptions of the UNESCO Convention, whose premise is that it is cultural diversity between nations and not within nations that needs to be protected and promoted, and this stance shapes the cultural policy measures taken by the State Parties.

On a more pragmatic level, it needs to be mentioned that in the context of trade and culture, “'the fight [...] is seldom over "high" culture,' which the US, like many other nations, routinely subsidizes. What is really at stake is control over the flow of, and capacity to profit from, popular culture." 32 What has been a thorn 185 in the side of all "exception culturelle" proponents is the fact that the U.S. content industries have been "America's most successful exporters." 33

A second misapprehension, although not as widely shared as the above and less politically charged, is that technological advances (which drive and are driven by globalization) negatively affect the diversity of cultural expressions demanding 190 more rather than less regulatory intervention. ${ }^{34}$ In the context of the now almost ubiquitous digital environment, this view lies upon shaky foundations, as we show in the next section, and reflects the transition dilemmas of media regulation, as noted above.

\section{The Changed Media Landscape}

When talking about trade and culture in the context of the WTO, the scope of the debate is in fact extremely narrow and has been concentrated almost exclusively on audiovisual services. ${ }^{35}$ Despite the considerable economic gains to be reaped from liberalization, nearly all Members, with the notable exception of the U.S., Japan, and New Zealand, have been reluctant to commit. ${ }^{36}$ In the ongoing Doha 200 Round, although the intensity of the confrontation has been lessened, there is little likelihood that Members will increase their level of commitments significantly. ${ }^{37}$

The unwillingness to commit relates to the perceived need for sufficient room to intervene to safeguard the role of audiovisual media as sustaining the public 
205 sphere and cultural and national identities. The underlying "axioms" of state intervention in this context have been (1) that some sort of additional regulation is indispensable because of the failures inherent to media markets ${ }^{38}$ and (2) that these market failures can be corrected through state measures (as the UNESCO Convention evidently purports). ${ }^{39}$ While these assertions can be questioned in all

210 sorts of respects, ${ }^{40}$ such discussions often boil down to the problem that both sides speak different languages, and economic arguments are subsumed under the politically driven propositions. ${ }^{41}$ Instead of engaging in arbitrary debates, we argue in the following that even if some sort of regulatory intervention were necessary in conventional media markets, this is not completely true for the contemporary

215 media landscape, which has been utterly changed with the advent and wide spread of digital media (in particular the Internet). The argument in support of this thesis is two-pronged and relates on the one hand to the modified mechanisms in digital media markets and on the other to the availability of new modes of creation, distribution, and access to cultural content.

220 At the core of these changes is the ability of the digital mode to express any type of information (e.g. words, images, or sounds) in binary digits. By reducing information to zeroes and ones, digital representation radically modifies the characteristics of content. For one, it is freed from the need for a tangible medium that contains it and it can be swiftly distributed at almost no cost. A second

225 salient feature that has caused much uproar with both big media conglomerates and small indigenous communities, is the ability to make perfect copies. ${ }^{42} \mathrm{~A}$ third, less noted, but perhaps the furthest reaching characteristic of digital media is that they have changed the way information is organized and accessed. ${ }^{43}$

Under the broader category of market-induced modifications in the digital

230 environment, ${ }^{44}$ as the reproduction, storage, and distribution of digital media products have a marginal cost close to zero, it becomes economically viable to sell relatively unpopular products. This creates incentives for suppliers to offer a larger and more diverse portfolio including also "non-hit" titles that appeal to smaller niche audiences. ${ }^{45}$ The digital setting also reduces the significant entrepreneurial

235 risk inherent in launching new cultural goods and services ${ }^{46}$ (at least for some of them), while making their visibility greater. This is in stark contrast to the substantial storage and distribution costs in the offline world, where the "shelf space"-be it TV prime time or a Christmas cinema weekend-is limited.

Traditional media companies have also faced horrendous promotion costs, 240 which were unbearable for smaller producers or individual artists. In the digital ecology, however, the supply and demand are somewhat more easily "connected" as the Internet allows searching through a single point of entry. This search process is also dynamic, and in addition to the conventional search engines, samples, feedback, and other advanced search tools based upon collective intelligence, ${ }^{47}$

245 enables users to discover even new products, eventually widening the diversity of content consumed. ${ }^{48}$ 
In the longer run, as the consumer becomes more empowered to choose as we move from a "push" to a "pul" mode of content consumption (i.e., from broadcasting to on-demand), it is conceivable that consumer selection will constantly generate new and/or niche products (similarly to the Amazon bookselling 250 platform ${ }^{49}$ ). This would have the effect of inducing markets to offer new types of content, including, for instance, archived or original works, documentaries or director's cuts, be they European, American, or African..$^{50}$ This may ultimately lead to a higher share of available and effectively consumed "good" works, which, if realized, would be a genuine expression of cultural diversity.

The second category of changes due to the properties and the dynamics of the digital space has to do with new modes of production of information, knowledge, and entertainment, whereby users become active creators, individually or as part of the community. ${ }^{51}$ Some of this user created content (UCC) reflects the key media policy components of diversity, localism, and noncommercial ${ }^{52}$ and may 260 become critical for the attainment of cultural objectives. ${ }^{53}$ The changes relate not only to what some call amateurs" $" 54$ but profoundly affect how all artists and culture-makers express themselves, how they communicate with one another and with the public, how cultural content is presented and made accessible, and how it is consumed. ${ }^{55}$

Against this backdrop, most of the currently applied "analogue-based" cultural policy measures, which are based primarily on the idea of protecting some "shelfspace" for culturally or nationally distinctive productions by putting up barriers to incoming foreign cultural goods and services, or privileging domestic ones, seem inappropriate, since the digital "shelf-space" is virtually unlimited. Furthermore, 270 if the "pull" model is to become the dominant model of consumption of media content, it is also impossible to "reserve" space for a certain purpose, since it is consumers themselves who decide on the content, its form, and time of delivery. We also need to think about the changed dimensions of markets: while not all markets for media content (be it music, video, or film) will be considered global in 275 the competition law sense, the digital environment does allow searching, finding, and accessing information without linking to the real-life location of the user. ${ }^{56}$ This certainly defies standard media regulation thinking, arguing that state intervention should be permitted to the extent that liberalized trade exacerbates market failures ${ }^{57}$ emphasizing among other things the enormous advantage of the U.S. 280 due to the size of its home market.

To wrap up the above arguments, one may legitimately question any cultural policy measure that restricts trade by erecting barriers to incoming foreign cultural goods and services under the conditions of a digital networked environment. If such measures are maintained, we hold that they serve either 285 protectionist $^{58}$ or political ${ }^{59}$ interests, or are the remnants of the ill-conceived (but politically widely accepted) perception of globalization and its effects upon culture. 
The digital environment is not, however, a panacea remedying all existing prob-

290 lems related to media. Indeed, we may see the emergence of new problems that require additional regulatory intervention, such as cyber-balkanization, ${ }^{60}$ extreme audience fragmentation, and an exacerbated split between digital and analogue households, not only in developing and least developed societies but also in developed societies. As national regulators grapple with these transformations, some

295 of which are still in their infancy, we may see the emergence of new priorities of media regulation, ${ }^{61}$ as well as new toolboxes to address them (e.g., no quotas, more subsidies for the creative industries), which are ultimately to be reflected at the international level.

\section{THE WTO: THE DEVIL IS NOT SO BLACK AS} HE IS PAINTED

As Wouters and de Meester note, "[c] ]haracterising the WTO agreements as solely trade-oriented and therefore culture-insensitive is not fully deserved." ${ }^{\prime 2}$ Indeed, if one looks into the evolutionary path of the trade and culture quandary, it was the General Agreement on Tariffs and Trade (GATT) 1947 that first ${ }^{63}$ accommodated some cultural concerns in the context of international trade after World War II, when the older but much smaller European industries received state protection against the incoming Hollywood supply. ${ }^{64}$ Article IV GATT reflected these policies and, while prohibiting quantitative restrictions of imports, ${ }^{65}$ it provided for some flexibility with regard to screening cinematograph films. ${ }^{66}$

310 Besides the leeway for screen quotas expressly devised in Article IV GATT, plenty of other norms scattered within the body of the WTO law can be found relevant and allow some flexibility as far as trade in cultural goods and services is concerned. In particularly, the General Agreement on Trade in Services (GATS) offers more wiggle room than the GATT, ${ }^{67}$ since the GATS framework involves

315 primarily a "bottom-up" (or "positive list") approach, whereby Members can choose the services sectors and subsectors in which they are willing to make national treatment or market access commitments and can define the modalities of these commitments. In contrast, obligations under GATT regarding national treatment and quantitative restrictions apply across the board, subject to specified exceptions (a "top-down" or "negative list" approach).

The scope for domestic measures regarding trade in culture was, however, never found sufficient. ${ }^{68}$ The inner tension between trade and culture has always been there, even within the GATT 1947-the WTO's less far-reaching institutional predecessor. This tension led to an explosion during the Uruguay Round 325 (1986-1994), when France and Canada fought the "exception culturelle" battle with the goal of exempting cultural services (in particular audiovisual ones) from the newly created agreement on services. ${ }^{69}$ The battle ended with an "Agreement 
to Disagree," whereby GATS covers all services sectors but permits significant commitment flexibilities. ${ }^{70}$ However, this was no real solution, and cultural proponents were well aware of this. Further liberalization was impending ${ }^{71}$ and the 330 MFN exemptions made were at least theoretically limited in time. ${ }^{72}$ A particularly hard blow to the cultural exception backers was the Canada-Periodicals case, ${ }^{73}$ decided by the Panel and the Appellate Body to the benefit of the U.S., despite the fact that the Canada-U.S. Free Trade Agreement (CUSFTA) ${ }^{74}$ envisaged a cultural exception clause.

Numerous proposals were advanced before and after the adoption of the UNESCO Convention to solve the "culture versus trade" conundrum and make it more like "culture and trade." One could group these suggestions (without claims for an exhaustive listing) into three categories.

The first attempts to insert a link that would connect the law of the WTO to 340 the UNESCO Convention, so that it would ultimately be for the WTO Panels and the Appellate Body to resolve the conflict. One proposition in this context is to introduce a "cultural" exception in the text of the WTO Agreements, similar to the ones existing for accommodating health or environmental concerns. ${ }^{75}$ Another suggestion has been to amend the text of the preamble of the WTO Agreement and 345 include the goal of cultural diversity next to that of sustainable development. This would arguably allow a Panel or the Appellate Body to interpret contested trade measures with the overarching objective of cultural diversity in mind, thereby balancing the interests at stake in the concrete conflict. ${ }^{76}$ Another option within this category, sketched by Graber, is the creation of a procedural link between 350 the WTO and the UNESCO rules, possibly through a Ministerial Decision, which "would oblige Members, in cases of conflict between trade and culture, to take into account the UNESCO Convention when interpreting and applying WTO law or entering into negotiations leading to an amendment of the WTO framework."77

In addition to the obvious difficulty of negotiating and adopting all these propos- 355 als, is the concern as to whether the WTO adjudicating bodies are the appropriate ones to decide upon such conflicts and whether they can really offer a solution that is comprehensive enough. This is a particularly valid doubt considering the UNESCO Convention's vagueness: to recall, the concept of cultural diversity is not concretely defined in the Convention and there are no clear rights and corre- 360 sponding obligations.

The second cluster of suggestions tries to modify the existing body of WTO law, so that it would become more culture-sensitive, i.e., allowing Members to pursue diverse cultural policy measures. In this context, a waiver for cultural policies negotiated under Article IX:3-4 of the WTO Agreement is the most radical 365 of options. It is also the least likely to materializes, since a waiver demands first a clear identification of the sector(s) concerned and second, the support of threequarters of the WTO membership. ${ }^{78}$ Other, subtler proposals put forward are in 
essence various types of cultural exemptions - not in the sense of a wide "excep-

tion culturelle" as France and Canada defined it during the Uruguay Round ${ }^{79}$ —but differentiated and justified by distinct (and presumably objective) characteristics inherent to cultural products and services. Bernier has suggested, for instance, an exception "for the preservation of cultural and linguistic diversity, including national cultures," 80 whereas Graber argues in favor of a cultural exemption restricted to the protection of art house films. ${ }^{81}$

However, as Voon quite rightly notes, all these proposals, besides the obvious difficulty of formulating them in a nonarbitrary and enforceable manner and of obtaining the Members' consent, are "regressive" in that they decrease the already achieved level of liberalization, especially for goods. ${ }^{82}$ Moreover, essentially all

380 of these suggestions are "academic" projects and not real politically driven ones that enjoy the support of WTO Members. In fact, as the UNESCO Convention clearly shows, the search for "trade and culture" solutions within the WTO have largely been given up. States are happy to maintain their low level of commitments (especially for audiovisual services) and find the escape to the forum of UNESCO

385 as security in this regard. Despite the impressive number of states that have ratified the Convention, and thus arguably committed to the objective of protecting and promoting cultural diversity, it is highly unlikely that a negotiating bloc within the WTO would form to push for some of the above "cultural" solutions. This is because when one looks at the political economy behind the adoption of the

390 Convention, there is not only one voice. Different states have ratified it for different reasons following their own specific agendas. ${ }^{83}$

Against this backdrop, it is perhaps better to consider options that are not so "culturally-coloured."

In this sense, the third category of suggestions we look at envisages amendments

395 to a number of WTO law norms or the introduction of new ones that improve the law of the WTO to reflect more appropriately the changes in the contemporary global space and to be clearer, more transparent, and enforceable. By undergoing this "renovation" process, it is also likely that norms will be put in place that allow simultaneous advancement of trade liberalization goals and consideration 400 of public interests and values of importance to Members and to the international community (including cultural diversity).

In view of the changing media environment, an important avenue for improving the WTO framework could be the reform of the existing services classification. Classification and scheduling issues have long been acknowledged as problem-

405 atic since the classification system used for services (the W/120 with reference to the United Nations Central Product Classification $(\mathrm{CPC})^{84}$ ) is rather inconsistent with the purpose of scheduling, is not detailed enough, has overlapping and/or outdated categories, and has not always been followed by the Members. A clearer, better structured, and up-to-date classification, especially with regard to 
the sectors pertinent to culture and the rapidly changing audiovisual and telecom- 410 munications areas, can be put high on the list of desiderata. Such an improved system could allow finer-tuned scheduling rather than the existing all-or-nothing" approach. ${ }^{85}$ It can also facilitate deeper market access commitments not only in the services sectors, such as computer and telecommunications services, where this may reasonably be expected.

Achieving a level of legal certainty with regard to this classification may also contribute to resolving the dilemma of classifying digitally transferred content (e.g. software, games, films, music). Currently and mostly because of the vehemently defended cultural considerations of the European Union (EU), it is not certain whether GATT or GATS applies. Furthermore, even if all parties would agree that the GATS modus is the appropriate one for digital content, it is unclear which service category would apply: online games, for instance, could be fitted into computer and related services, value-added telecommunications services, or entertainment or audiovisual services. ${ }^{86}$ This is also true for other new and emerging services, which were not available at the time the GATS was negotiated. 425

As a more comprehensive improvement plan, there is a good deal to be achieved by taking up the unfinished business of the Uruguay Round. The "framework of GATS rules and disciplines is still very much under construction"87 and needs to be completed with rules on (a) emergency safeguard measures (Article X:1), (b) subsidies (Article XV:1), (c) government procurement (Article XIII:2), and (d) 430 domestic regulation (Article VI:4).

While all of these projects would make the rules of the GATS finer-grained, thereby allowing also better tuned commitments, new rules on subsidies ${ }^{88}$ are to be viewed as particularly appropriate in the context of "trade and culture." The audiovisual sector is one of the traditionally subsidized ones ${ }^{89}$ and "often subsidies 435 are the most efficient instrument for pursuing noneconomic objectives," also for the protection and promotion of local or national culture. Furthermore, the U.S. has noted in this respect that "Members may also want to consider developing an understanding on subsidies that will respect each nation's need to foster its cultural identity by creating an environment to nurture local culture,"91 440 so there may be some tolerance already.

Yet, in view of the little progress made so far toward creating horizontally applicable rules on subsidies, the lack of data and, most importantly, the "decidedly limited political appetite for forward movement," it seems apt to argue in favor of elaborating a limited number of ad hoc instruments. ${ }^{92}$ This is also the approach followed by Tania Voon, ${ }^{93}$ who advocates allowing "a limited exception for Members to impose discriminatory cultural policy measures in the form of subsidies in preference to any other form. ${ }^{94}$ Voon argues for a narrow definition of subsidies similar to that for goods in the Agreement on Subsidies and Countervailing Measures, ${ }^{95}$ and for allowing both de jure (based on the origin of the service or service 450 supplier) and de facto (based on objective and transparent cultural criteria such as language) discrimination in the granting of subsidies. ${ }^{96}$ 
Finally, in the third category of suggestions, one needs to mention the possibility of inserting competition rules within the WTO legal framework ${ }^{97}$ that would deal with market distortions by private undertakings. Such rules could be particularly helpful considering that digital media are by default global in their distribution and new media providers operate regardless of borders. This is however perhaps the least feasible of avenues, bearing in mind the little progress made since Singapore ${ }^{98}$ and that the issue was dropped from the Doha agenda. ${ }^{99}$

460 To sum up, while the WTO Agreements have been generally held not to provide sufficient flexibilities or to be capable of accommodating cultural policy measures, there are various ways in which this could be remedied. Unfortunately, the overpoliticized disconnect of regulatory issues of trade and culture renders all these suggestions mere "brain games," highly unlikely ever to be realized. Among these proposals, however, there are also such that are not in themselves culturally motivated but rather seek to improve the overall WTO structure of rules (in particular of the GATS), making it more flexible, comprehensive, and transparent. Using these "neutral" paths, such as improved classification or new rules on subsidies for services, may allow simultaneous framing of both economic and public interest rationales.

Unlike the framework of rules, institutions, and procedures created by the UNESCO Convention, the WTO Agreements offer more legal certainty, fairness, and enforceability, and contain mechanisms for evolutionary development through negotiation and adjudication. In this sense, one could argue that, although their

475 focus is not on issues of culture, the WTO Agreements can very well cater for the "trade and culture" ones.

\section{CONCLUSION}

The case of "trade versus culture" is becoming increasingly attractive for politicians as the popularity of globalization wanes, in particular in industrialized countries $^{100}$ and as national values and interests, especially after the $9 / 11$, gain prominence. ${ }^{101}$ Yet, the politically driven disconnect between trade and culture, while easily justified before the constituencies concerned, is not necessarily beneficial for either the domain of trade or that of culture. The relationship between the two is somehow natural and indeed it has been explicitly recognized by the UNESCO

485 Convention that cultural goods and services have dual natures and constitute on the one hand, commodities that can be traded and are "vehicles of identity, values, and meaning," 102 on the other.

A politically laden and increasingly widening gap between issues of trade and culture may be unfortunate, we hold, and may substantially reduce the chances of creating coherent regulatory models, which are trade-conducive, while sufficiently accommodating public interest objectives. This hypothesis is not only a critique of the current approaches but also relates to our premise that a "trade versus culture" 
confrontation does not reflect the practical reality of contemporary cultural content creation, distribution, and consumption. We argued that the digital networked environment, which has now become pervasive, has radically altered the dynamics 495 of cultural content markets, as well as the conditions for creativity and innovation, and may call for a reevaluation of the policy tools for the attainment of cultural diversity. We suggested in particular that any trade restriction may in fact be counterproductive to a thriving cultural environment, and that the focus on "trade versus culture," especially in the classical discussion of audiovisual media services, 500 may be too narrow and may fail to recognize the augmented significance of other domains (such as copyright).

We also, and at times harshly, criticized the UNESCO Convention, which in its present form, can be construed as little more than an extension of the "Agreement to Disagree," 103 although framed under a new forum. As "trade in cultural products 505 continues to grow, the Convention [ ...] is counterintuitive at best and completely off the mark at worst." 104 In contrast, we held that there are various ways in which the WTO could become more conducive to cultural considerations. The path dependencies relating to audiovisual services and anything to do with culture (and by simplified extension, with national sovereignty) are, however, too strong 510 to allow any forward movement at this stage. Using means that are not necessarily "cultural" on their face may be (at least partially) a solution to this problem, although being aware of the complexity of the negotiation process, we do not fantasize that there is soon to be a substantial advancement in any of the aspects discussed.

The profoundly changed (and changing) media landscape may offer an opportunity to rethink the old "analogue" audiovisual media rules and the wider context of "trade and culture." As national regulators start to grapple with digital media and their regulatory implications, we are likely to observe the emergence of new tools that instead of merely reserving some "shelf-space" for domestic produc- 520 tions, foster creativity, interactivity, distribution and reuse of information. ${ }^{105}$ The new models would call for readjustment of the international commitments of these states and perhaps press on for some changes within the WTO.

As Galt prognosticates,

... consumer sovereignty, technological change, and perhaps another dominant voice within the European Union will prove too powerful to keep in check. The collective hand of EU negotiators will be forced to make further concessions and jumpstart GATS negotiations in the audiovisual sector, perhaps extracting valuable concessions from the United States in other sectors. However, if the "trade and culture" linkage is not squarely addressed soon, the European Union may find itself in a position whereby its concessions in the audiovisual sector are of little value at the negotiating table... ${ }^{106}$ 
especially if we bear in mind that the U.S. has already found comfortable solutions for digital media trade in its FTAs. Pressure upon the "cultural exception"

535 exponents is also likely to be exerted by developing countries, which may not be satisfied with the cultural cooperation promises under the UNESCO Convention ${ }^{107}$ and actively search for real market access concessions. Such an aspiration would not be misplaced, since "even a cursory look at international trade in cultural products shows" that "developed countries at the forefront of efforts to 'protect' cultural diversity are at the forefront of cultural trade as well."108

Speculating about the longer term dimension of the relationship between trade and culture, we may very well expect a "return" to the WTO framework as a sort of reconciliation within the pair, but also new domestic regulatory initiatives that address new problems that the digital environment brings about.

1. 148 countries voted for the adoption of the Convention, while four countries (Australia, Honduras, Nicaragua, and Liberia) abstained. Only two countries, the U.S. and Israel, opposed. As of September 28, 2010, 115 countries, as well as the European Community, had ratified the UNESCO Convention (see $\mathrm{http}$ ://portal.unesco.org/la/convention.asp?KO=

$55031038 \&$ language $=\mathrm{E}$ (accessed 18 March 2011).

2. Rachael Craufurd Smith, The UNESCO Convention on the Protection and Promotion of Cultural Expressions: Building a New World Information and Communication Order? 1 INTERNATIONAL JOURNAL OF COMMUNICATION 24, 28-29 (2007).

3. Christoph Beat Graber, The New UNESCO Convention on Cultural Diversity: A Coun-

555 terbalance to the WTO. 9 JOURNAL OF INTERNATIONAL ECONOMIC LAW 553, 564-65 (2006).

4. See Frederick Scott Galt, The Life, Death, and Rebirth of the "Cultural Exception" in the Multilateral Trading System: An Evolutionary Analysis of Cultural Protection and Intervention in the Face of American Pop Culture's Hegemony. 3 WASHINGTON UNIVERSITY

560 Global StUdies LaW REVIEW 909-35 (2004).

5. Canadian Cultural Industries Sectoral Advisory Group on International Trade (SAGIT), New Strategies for Culture and Trade: Canadian Culture in a Global World, 1999, at Executive Summary.

6. Articles 7-19 UNESCO Convention. The only provision of binding nature (Article 16)

565 resembles the WTO's enabling clause and relates to the preferential treatment for developing countries, whereby developed countries must facilitate cultural exchanges with developing countries by granting preferential treatment to cultural workers, as well as to cultural goods (see GATT, Decision of 28 November 1979 (L/4903), Differential and More Favourable Treatment, Reciprocity and Fuller Participation of Developing Countries).

5707 7. Craufurd Smith, supra note 2, at 39; Article 9(a) UNESCO Convention. 8. Article 6(2)(a)-(h) UNESCO Convention. For an overview of the domestic cultural policy measures, see Mary E. Footer and Christoph Beat Graber, Trade Liberalisation and Cultural Policy. 3 Journal OF InTERNATIONAL ECONOMIC LAW 115, 122-26 (2000).

9. Craufurd Smith, supra note 2, at 40. In this sense, it also diverges from the contemporary

575 theory of regulation seeking the slightest possible interference (see e.g. RICHARD R. NELSON (ED.), THE LIMITS OF MARKET ORGANISATION (2005). 
10. Craufurd Smith, supra note 2, at 40-41.

11. Article 4(1) defines "cultural diversity" as referring "to the manifold ways in which the cultures of groups and societies find expression."

12. See e.g. Craufurd Smith, supra note 2; Jan Wouters and Bart De Meester, The UNESCO 580

Convention on Cultural Diversity and WTO Law: A Case Study in Fragmentation of International Law. 41 JOURNAL OF TRADE LAW 205-40; Christopher M. Bruner, Culture, Sovereignty, and Hollywood: UNESCO and the Future of Trade in Cultural Products. 40 InTERNATIONAL LAW AND POLITICS 351-436 (2008); Mira Burri-Nenova, Trade versus Culture in the Digital Environment: An Old Conflict in Need of a New Definition. 12585 JOURNAL OF INTERNATIONAL ECONOMIC LAW 1-46 (2009).

13. ElSA StAmatopoulou, CUltural RightS in INTERNATIONAL LAW (2007).

14. Craufurd Smith, supra note 2, at 28 and 37.

15. Recitals 8, 13, and 15 of the preamble, Articles 2(3) and 7(1)(a) UNESCO Convention. 16. The Convention also in this sense ignores recent developments in international law, 590 such as the United Nations Declaration on the Rights of Indigenous Peoples, adopted with General Assembly Resolution 61/295, 13 September 2007.

17. Craufurd Smith, supra note 2, at 26 and 28.

18. Recital 17 UNESCO Convention's preamble recognizes "the importance of intellectual property rights in sustaining those involved in cultural creativity." IPRs had a more 595 prominent role during the negotiations of the Convention. See Laurence R. Helfer, Towards a Human Rights Framework for Intellectual Property. 40 UC DAVIS LAW REVIEW 971, 1004-6 (2007).

19. As the U.S. Constitution (Article I, Section 8, para 8) beautifully puts it: "[t]o promote the Progress of Science and useful Arts, by securing for limited Times to Authors and 600 Inventors the exclusive Right to their respective Writings and Discoveries."

20. Raymond Shih Ray Ku, Promoting Diverse Cultural Expression: Lessons from the US Copyright Wars. 2 ASIAN JOURNAL OF WTO AND INTERNATIONAL HEALTH LAW AND POLICY (AJWH) 369, 376 (2007).

21. Tomer Broude, Conflict and Complementarity in Trade, Cultural Diversity and Intel- 605 lectual Property Rights. 2 ASIAN JOURNAL OF WTO AND INTERNATIONAL HEALTH LAW AND POLICY (AJWH) 346, 355-56 (2007).

22. Craufurd Smith, supra note 2, at 53-54.

23. Craufurd Smith, supra note 2, at 29-30.

24. The Multilateral Trade Regime: Which Way Forward?, The Report of the 610 FIRST WARWICK COMMISSION, at 26 (2007).

25. For some classic thoughts, see Paul Krugman, Competitiveness: A Dangerous Obsession. 73 FOREIGN AFFAIRS 28-44 (1994).

26. For a critique of the cultural industries and the homogeneity of content, see CHRISTOPH BEAT GRABER, HANDEL UND KULTUR IM AUDIOVISIONSRECHT DER WTO, at 18 et seq. 615 (2003).

27. See e.g. ANTHONY GIDDENS, RUNAWAY WORLD: HOW GLOBALISATION IS RESHAPING OUR LIVES (2002). With regard to culture, Giddens (at xxiv) holds that "Western, and more specifically American, cultural influence is visible everywhere-in films, television, popular music and other areas. Cultural standardisation is an intrinsic part of this process. Yet all this is relatively superficial cultural veneer; a more profound effect of globalisation is to produce greater local cultural diversity, not homogeneity. The United States itself is the very opposite of a cultural monolith, comprising as it does a dazzling variety of different ethnic and cultural groups. Because of its 'push-down' effect [...] globalisation tends to promote a renewal of local cultural identities. Sometimes these reflect wider world patterns, but very often they self-consciously diverge from them." Tyler Cowen also insists that global monopolies and imported technologies have led to promoting local creativity 
by generating new markets for innovative, high-quality artistic productions. See TYLER Cowen, Creative Destruction: How Globalization Is Changing the World's

630 Cultures, at 146 (2002).

28. Bruner, supra note 12, at 432.

29. Tom O'Regan and Ben Goldsmith, Making Cultural Policy: Meeting Cultural Objectives in a Digital Environment. 7 TELEVISION AND NEW MEDIA 68, 88 (2006).

30. Madhavi Sunder, Cultural Dissent. 54 STANFORD LAW REVIEW 495, 498 (2001).

635 31. Yudhishtir Raj Isar, Cultural Diversity. 23 THEORY, CULTURE AND SOCIETY 371, 372 (2006), referring to Nick Stevenson, Cultural Citizenship: Cosmopolitan QuesTIONS, at 62 (2003).

32. Bruner, supra note 12.

33. Bonnie J. K. Richardson, Vice-President of Trade and Federal Affairs, Motion Picture

640 Association of America, Impediments to Digital Trade: Hearing before the Subcommission on Commerce, Trade and Consumer Protection of the House Committee on Energy and Commerce, 107th Congress 17, 2001.

34. See Graber, supra note 3, at 570.

35. In the WTO context, audiovisual services encompass motion picture and video tape

645 production and distribution services, motion picture projection service, radio and television services, radio and television transmission services, sound recording and others. See WTO, Services Sectoral Classification List, WTO Doc.MTN.GNS/W/120, 10 July 1991, at 2(D).

36. Martin Roy, Audiovisual Services in the Doha Round: Dialogue de Sourds, The Sequel?

6506 JOURNAL OF WORLD INVESTMENT AND TRADE 923-52 (2005).

37. Id. at $931-36$.

38. The most prominent reference is C. EDWIN BAKER, MEDIA, MARKETS, AND DEMOCRACY (2001).

39. Wouters and De Meester, supra note 12, at 217.

655 40. Galt, supra note 4, 917-19. See also generally Richard A. POSNER, THE ECONOMIC ANALYSIS OF LAW (7th ed. 2007).

41. There are economic models that show that trade restrictions enhance welfare. Such a cultural trade model involving two countries, the U.S. and France, in which a French tariff on film imports can be optimal, is valid, however, with the critical assumptions

660 that Hollywood can produce exportable films but the French industry cannot; nationals of one country cannot invest or participate as professionals in the other's film industry, and there is no price discrimination. See Patrick François and Tanguy van Ypersele, On the Protection of Cultural Goods. 56 JOURNAL OF INTERNATIONAL ECONOMICS 359-69 (2002).

665 42. See e.g. Mira Burri-Nenova, The Long Tail of the Rainbow Serpent: New Technologies and the Protection and Promotion of Traditional Cultural Expressions, in INTELLECTUAL PROPERTY AND TRADITIONAL CULTURAL EXPRESSIONS IN A DIGITAL ENVIRONMENT 205-36 (Christoph Beat Graber and Mira Burri-Nenova eds., 2008).

43. DAVID WEINBERGER, EVERYTHING IS MisCELlANEOUS (2007).

670 44. Chris Anderson, The LONG TAIL: Why thE Future OF Business Is SElling Less OF MoRE (2006). See also Erik Brynjolfsson, Yu Hu, and Michael D. Smith, From Niches to Riches: The Anatomy of the Long Tail. 47 SLOAN MANAGEMENT REVIEW 67-71 (2006). 45. This may also be true for offering products in diverse languages. While most websites are still in English, it is a fact that as the Internet becomes ubiquitous people around the

675 world prefer to read their news, stories, and local gossip in their own language. The free online encyclopedia Wikipedia, for instance, while having the greatest number of articles in English $(3,587,947)$, exists also in 278 other languages. See http://meta.wikimedia.org/ wiki/List_of_Wikipedias (accessed 18 March 2011). 
46. Germann argues that this specificity of cultural goods and services is the main one that commands intervention. Christophe Germann, Culture in Times of Cholera: A Vision for a 680 New Legal Framework Promoting Cultural Diversity. 6 ERA-FORUM 109, 116 (2005). 47. Also called wisdom of the crowds. See JAMES SUROWIECKI, THE WISDOM OF CROWDS: Why the Many Are SMarter Than the FeW and How Collective Wisdom Shapes BUSINESS, ECONOMIES, AND NATIONS (2003).

48. Brynjolfsson et al., supra note 44.

49. ERIK Brynjolfsson, Yu Hu, and Michael D. SMith, Consumer Surplus in the Digital ECONOMY: ESTIMATING THE VALUE OF INCREASED PRODUCT VARIETY AT ONLINE BOOKSELLERS, MIT SLOAN WORKING PAPER NO 4305(2003).

50. EDWIN HORLINGS, CHRIS MARSDEN, CONSTANTIJN VAN ORANJE, AND MAARTEN BotTERMAN, CONTRIBUTION TO IMPACT ASSESSMENT OF THE REVISION OF THE TELEVISION 690 WITHOUT FRONTIERS DIRECTIVE, at 66 (2005).

51. A 2007 OECD Report summarizes these effects stating that "[t]he Internet as a new creative outlet has altered the economics of information production and led to the democratization of media production and changes in the nature of communication and social relationships $[\ldots]$. Changes in the way users produce, distribute, access and re-use information, knowledge and entertainment potentially give rise to increased user autonomy, increased participation and increased diversity." See OECD, Participative Web: User-Created Content, DSTI/ICCP/IE(2006)7/FINAL, 12 April 2007, at 5.

52. Ellen P. Goodman, Media Policy Out of the Box: Content Abundance, Attention Scarcity, and the Failures of Digital Markets. BerKeley TeCHNOLOGY LAW JOURNAL 1389, 1395-99 (2004). For case studies, see also News and Information as Digital Media Come of Age, Report of the Berkman Center for Internet and Society at Harvard University, 18 December 2008.

53. For a specific analysis of UCC in virtual worlds, see Mira Burri-Nenova, User Created Content in Virtual Worlds and Cultural Diversity, in GOVERNANCE OF DigITAL GAME 705 ENVIRONMENTS AND CUltural Diversity 74-112 (Christoph Beat Graber and Mira Burri-Nenova, eds., 2009).

54. For a critical opinion, see ANDREW KeEn, THE Cult of THE AMATEUR: How TODAY'S INTERNET IS KILLING OUR CULTURE (2007).

55. See Netherlands Council for Culture, From ICT to E-Culture: Advisory Report on the Digitalisation of Culture and the Implications for Cultural Policy, submitted to the State Secretary for Education, Culture and Science, 2003; Tom O'Regan and Ben Goldsmith, Emerging Global Ecologies of Production, in THE NEW MEDIA BOOK 92-105 (Dan Harries, ed., 2008).

56. Here one should however acknowledge the possibilities of filtering information on the 715 Internet, mostly done for political reasons. See RonAld J. DEIBERT, JOHN G. PALFREY, RAFAl ROHOZINSKI, AND JoNATHAN ZITTRAIN, ACCESS DENIED: THE PRACTICE AND POLICY OF GLOBAL INTERNET FILTERING (2007).

57. Baker, supra note 38, at 121.

58. Such as, for instance, the EC TV quotas for European content, as we have argued 720 elsewhere. See Mira Burri-Nenova, The New Audiovisual Media Services Directive: Television without Frontiers, Television without Cultural Diversity. 44 COMMON MARKET LAW REVIEW 1689-725.

59. In the sense of supporting a political regime as in China. See Henry Gao, The Mighty Pen, the Almighty Dollar and the Holy Hammer and Sickle: Examination of the Conflict 725 between Trade Liberalization and Domestic Cultural Policy with Special Regard to the Recent Dispute between the United States and China. 2 ASIAN JOURNAL OF WTO AND INTERNATIONAL HEALTH LAW AND POLICY (AJWH) 313-43. 
60. Marshall Van Alstyne and Erik Brynjolfsson, Global Village or Cyber-Balkans? Model-

730 ing and Measuring the Integration of Electronic Communities. 51 MANAGEMENT SCIENCE 851-68 (2004).

61. For some suggestions, see Mira Burri-Nenova, The Changing Environment of Audiovisual Media: New Technologies, New Patterns of Consumer/Business Behaviour and Their Implications for Audiovisual Media Regulation. MEDIALEX 171-77 (2007).

735 62. Wouters and De Meester, supra note 12, at 218.

63. In the context of UNESCO, it was only in the 1990s that the organization took a concrete interest in protecting cultural diversity from the alleged negative effects of international trade and economic globalization. Key steps in this process were the publication of the seminal report "Our Creative Diversity" by the World Commission on Culture and Development

740 in 1995 and the 1998 Stockholm Conference on Cultural Policies for Development. See Bruner, supra note 12 , at $378-83$.

64. JOHN TRUMPBOUR, SELLING HOLLYWOOD TO THE WORLD: US AND EUROPEAN STRUGGLES FOR MASTERY OF THE GLOBAL FILM INDUSTRY, 1920-1950 (2007).

65. Article XI GATT.

745 66. Article IV GATT covers "internal quantitative regulations relating to exposed cinematograph films," which must take the form of "screen quotas" conforming to certain requirements (Article IV, paras (a) to (d)). Such quotas "may require the exhibition of cinematograph films of national origin during a specified minimum proportion of the total screen time actually utilized" and may "reserve a minimum proportion of screen time for

750 films of a specified origin other than that of the Member imposing such screen quotas." 67. Graber, supra note 3, at 555 and 569.

68. See Sandrine Cahn and Daniel Schimmel, The Cultural Exception: Does It Exist in GATT and GATS Frameworks? How Does It Affect or Is It Affected by the Agreement on TRIPS? 15 CARDOZO ARTS AND ENTERTAINMENT LAW JOURNAL 281, 287-89 (1997).

755 69. See Christoph Beat Graber, Audio-visual Policy: The Stumbling Block of Trade Liberalisation, in THE WTO AND GLOBAL CONVERGENCE IN TELECOMMUNICATIONS AND AUDIOVISUAL SERVICES 165-214 (Damien Geradin and David Luff eds. 2004); Roy, supra note 36 .

70. Galt, supra note 4, at 914; Cahn and Schimmel, supra note 68, at 291-301.

760 71. See Part IV GATS. Article XIX therein states: 'In pursuance of the objectives of this Agreement, Members shall enter into successive rounds of negotiations, beginning not later than five years from the date of entry into force of the WTO Agreement and periodically thereafter, with a view to achieving a progressively higher level of liberalization'.

72. The GATS Annex on Article II Exemptions states that, "[i]n principle, such exemptions

765 [to MFN] should not exceed a period of 10 years. In any event, they shall be subject to negotiation in subsequent trade liberalizing rounds'. The exemptions made should have thus theoretically expired in 2005.

73. WTO Panel Report, Canada-Certain Measures Concerning Periodicals (Canada-Periodicals), WT/DS31/R, adopted 14 March 1997; WTO Appellate

770 Body Report, Canada-Certain Measures Concerning Periodicals (Canada-Periodicals), WT/DS31/AB/R, adopted 30 June 1997.

74. Canada-US Free Trade Agreement, 22 December 1987-2 January 1988, 27 ILM 281 (1988).

75. See Article XX(b) GATT and Article XIV(b) GATS with regard to measures "necessary

775 to protect human, animal or plant life or health', and Article XX(g) GATT with regard to measures 'relating to the conservation of exhaustible natural resources'.

76. See WTO Appellate Body Report, United States-Import Prohibition of Certain Shrimp and Shrimp Products (US-Shrimp), WT/DS58/AB/R, adopted 12 October 1998, at para 17. 
77. Graber, supra note 3, at 572.

78. Chi Carmody, When "Cultural Identity Was Not an Issue": Thinking about 780 Canada-Certain Measures Concerning Periodicals. 30 LAW AND POLICY IN INTERNATIONAL BUSINESS 231-320 (1999).

79. For an account of the different positions, see Roy, supra note 36, at 926-28.

80. Ivan Bernier, Cultural Goods and Services in International Trade Law, in THE CuLTURE/TRADE QUANDARY 147 (Dennis Browne ed. 1998).

81. See Christoph Beat Graber, WTO: A Threat to European Film?, in ProceEdINGS of THE 5TH CONFERENCE "EuROPEAN CUlTuRE” 865-78 (Enrique Banus ed. 2000). Graber suggests that such art house films could be differentiated, instead of using otherwise subjective qualitative assessment, by applying a quantitative criterion for film budgets of not more than 5 million USD.

82. Tania Voon, A New Approach to Audiovisual Products in the WTO: Rebalancing GATT and GATS. 14 UCLA ENTERTAINMENT LAW REVIEW 1, 27 (2007).

83. For instance, Brazil, Japan and India have all ratified the Convention but remain equally willing to engage in further liberalization of the audiovisual sector.

84. UN Provisional Central Product Classification (CPC), UN Statistical Papers, Series M, 795 No 77, Ver.1.1, E.91.XVII.7, 1991.

85. Roy, supra note 36, at 947.

86. Sacha Wunsch-Vincent, The WTO, the Internet and Trade in Digital ProdUCTS, at 71 (2006).

87. Pierre Sauvé, Completing the GATS Framework: Addressing Uruguay Round Leftovers. 800 3 AUSSENWIRTSCHAFT 301, 302 (2002).

88. While the GATS contains no specific rules on subsidies, these are not excluded from its scope. As "measures by Members affecting trade in services" within the meaning of Article I:1, subsidies are fully covered by the provisions of the GATS. A number of GATS provisions restrict governments' ability to provide services subsidies or to offer a remedy to those Members harmed by their negative effects. See Pietro Poretti, Waiting for Godot: Subsidy Disciplines in Services Trade, in GATS AND THE REgULATION OF INTERNATIONAL TRADE IN SERVICES 466-48 (Marion Panizzon et al. eds 2008).

89. Sauvé, supra note 87 , at 325.

90. Bernard Hoekman, Toward a More Balanced and Comprehensive Services Agreement, 810 in THE WTO AFTER SEATTLE 119, 129 (Jeffrey J. Schott ed. 2000).

91. WTO, Communication from the United States, Audiovisual and Related Services, S/CSS/W/21, 18 December 2000, at para 10(iii). The U.S. has already accepted some leeway for subsidies in its FTAs with Singapore and Australia.

92. Poretti, supra note 88 , at 486.

93. Voon, supra note 82 , at 20-24.

94. Id. at 20.

95. WTO, Agreement on Subsidies and Countervailing Measures, at Article 1.1(a)(i) and (ii).

96. Voon, supra note 82, at 22.

97. Philip MARSDEN, A COMPETITION POLICY FOR THE WTO (2003).

98. WTO, Singapore Ministerial Declaration, Conf. Doc. WT/MIN(96)/DEC/W, 13 December 1996. The Singapore Declaration mandated the establishment of "a working group to study issues raised by Members relating to the interaction between trade and competition policy, including anti-competitive practices, in order to identify any areas that may merit 825 further consideration in the WTO framework."

99. WTO, Doha Work Programme: Decision Adopted by the General Council on 1 August 2004, WT/L/579, 2 August 2004, at para (g). 
100. The Warwick Commission, supra note 24, at 9 and ch. 1.

830 101. For a critique of the cultural exception doctrine, see Galt, supra note 4, at 915-22.

102. Article 1(g) UNESCO Convention.

103. Galt, supra note 4, at 933 .

104. Singh, supra note 31 , at 48 .

105. The British Broadcasting Company (BBC) has already experimented in this field.

835 See Ofcom, "A New Approach to Public Service Content in the Digital Media Age: The Potential Role of Public Service Publisher" (Ofcom Discussion Paper, January 24, 2007); Jamie Cowling and Damien Tambini eds., From Public Service Broadcasting to Public SERVICE COMMUNICATIONS (2004).

106. Galt, supra note 4, at 935, meaning the United Kingdom as the new dominant voice 840 within the EU.

107. Articles 14, 16, and 18 UNESCO Convention. Many developing countries ratified the Convention in the hope that they would profit from the International Fund for Cultural Diversity, created under the Convention (Article 18).

108. Singh, supra note 31 , at 42 . 